\title{
PERAN PEREMPUAN DALAM PELESTARIAN LINGKUNGAN DI KEPULAUAN KARIMUNJAWA JEPARA, JAWA TENGAH
}

\author{
Mochamad Widjanarko \\ Universitas Muria Kudus \\ m.widjanarko@umk.ac.id
}

\section{ABSTRAK}

Tujuan Penelitian adalah menganalisis peran perempuan dalam melestarikan lingkungan di Kepulauan Karimunjawa Jepara. Penelitian ini adalah penelitian kualitatif dengan pendekatan fenomenologis. Pengumpulan data yang digunakan adalah wawancara mendalam dan pengamatan. Analisis data yang digunakan adalah koding, dengan membubuhkan kode-kode pada materi yang diperoleh.Koding dimaksudkan untuk dapat mengorganisasi dan mensistemasi data secara lengkap dan mendetail sehingga data-data dapat muncul gambaran tentang topik yang diteliti.Hasil temuan penelitian ini menunjukkan bahwa salah satu peran perempuan dalam melestarikan lingkungan di Kepulauan Karimunajawa adalah mengelola sampah, yang dilakukan dengan membentuk bank sampah dan mengajak keluarga serta orang lain untuk mengelola sampah. Sedangkan informan yang memiliki rumah penginapan juga menggunakan air secara bijak dan memilah sampah dalam bentuk sampah organik dan nonorganik.Untuk informan yang berprofesi guru selain menanam tanaman yang bisa diperlukan sehari-hari juga mengajak muridnya dalam menjaga lingkungan di sekitar sekolah dan upaya melakukan bersih-bersih pantai.

Kata kunci: Karimunjawa, Pelestarian Lingkungan, Peran Perempuan 


\section{ABSTRACT}

The aim of this study is to analyze the role of women in preserving the environment in the Karimunjawa Islands Jepara. This research is a qualitative research with a phenomenological approach. The data collection used are in-depth interviews and observations. The data analysis research used is coding, by putting the codes on the material obtained. Coding is intended to be able to organize and systemize data in a complete and detailed manner so that data can appear in the description of the topic under study. From the findings of the study it can be concluded: one of the roles of women in preserving the environment in Karimunajawa Islands is to manage waste, which is done by forming a waste bank and inviting families and other people to manage waste. While informants who have lodging houses also use water wisely and sort waste in the form of organic and non-organic waste. For informants who are teachers, besidesplanting crops that is needed everyday, they are able to invite their students to take care of the environment around the school and clean the beach.

Keywords: Karimunjawa, Environmental Conservation, Women's Role

\section{A. Pendahuluan}

Pembangunanekonomidi Indonesia telahmeletakkan perempuan sebagai obyek atau sasaran pembangunan dan perempuan hanyalah penerima pasif pembangunan. Pembangunan yang timpang telah merusak kesatuan kerja antara lelaki dan perempuan serta menempatkan lelaki tanpa konsep feminim diatas alam dan perempuan, terpisah dari keduanya.Kegiatan produktifitas dan kreativitas yang menjadi prinsip feminin diambil alih dan diubah, dijadikan milik lelaki semata.Perempuan dan alam diubah menjadi manusia pasif, digunakan untuk dapat dikendalikan oleh kaum laki laki. Kebijakan dan praktekpraktek kontraekologis seperti: hutan-hutan dibabati, tambang dikeruk habis-habisan, pantai diprivatisasi, kota- 
kota dipenuhi hutan-hutan beton, telah menenggelamkan peran perempuan dalam mengelola lingkungan.

Kepulauan Karimunjawa termasuk dalam wilayah Kabupaten Jepara, Jawa Tengah, terletak 45 mil di sebelah Barat Laut Kota Jepara pada koordinat $5^{\circ} 40^{\prime}$ - 5 $57^{\circ}$ LS dan $110^{\circ} 04^{\prime}$ - $110^{\circ} 40^{\prime}$ BT.Kepulauan karimunjawa ditetapkan sebagai kawasan konservasi (Cagar Alam Laut) sejak tahun 1986, kemudian dinyatakan sebagai Taman Nasional Laut pada tahun 1988 seluas 111.625 hektar, terdiri dari 1.505,4 hektar daratan dan 110.019,6 hektar perairan. Pada tahun 2001 sebagian kawasan Taman Nasiional Karimunjawa seluas 110.117,3 hektar ditetapkan sebagai Kawasan Pelestarian Alam Perairan.Total luas Taman Nasional Karimunjawa darat dan perairan adalah 110.625 ha.

Kepulauan terpencil Karimunjawa dibatasi atau dilingkupi Laut Jawa dengan luas 7.120 Ha yang terdiri dari 27 pulau. Terdapat lima pulau yang berpenghuni, yaitu Pulau Karimunjawa, Pulau Kemojan, Pulau Parang, Pulau Nyamuk dan Pulau Genting yang terbagi dalam empat desa. Pertama, Desa Karimunjawa terdiri dari 6 dukuh yaitu Karimunjawa, Jati Kerep, Alangalang, Nyamplungan, Ciekmas dan Genting. Kedua, Desa Kemojan dengan 4 (empat) dukuh yaitu Kemojan, Telogo, Mrican dan Batulawang. Ketiga Desa Parang dan keempat, Desa Nyamuk (BPS Kabupaten Jepara, Kecamatan Karimun dalam Angka, 2013).

Data monografi desa mengungkapkan bahwa jumlah penduduk Kecamatan Karimunjawa pada tahun 2013 mencapai 9.018 jiwa dengan perbandingan antara jumlah laki-laki sebanyak 4.541 jiwa dan perempuan sebanyak 4.477 jiwa. Penduduk Karimunjawa tersebar dalam 3 desa, yaitu Karimunjawa, Kemujan dan Parang dalam satu wilayah kecamatan.Sebagian besar penduduk adalah nelayan yang menggantungkan hidupnya pada 
potensi laut.Penghasilan utama dari ikan laut terutama dari pemanfaatan sumber daya perikanan.

Mengingat campur tangan manusia terhadap alam ibarat pisau bermata dua yaitu bersifat merusak atau melestarikan alam, maka pilihan kedualah yang tentunya kita dukung dalam jangka waktu ke depan. Sudah terbukti, campur tangan manusia yang peduli lingkungan bisa sangat bermanfaat bagi kelestarian alam, walaupun hanya dilakukan sebagian kecil anggota masyarakat.

Konsep pembangunan berkelanjutan yang adil gender atau meningkatkan kualitas hidup manusia dengan hidup dalam kapasitas sumberdaya bumi yang tetap untuk memenuhi kebutuhan generasi sekarang, juga memperhitungkan kebutuhan generasi mendatang serta memperhatikan peran perempuan merupakan salah satu pilihan yang harus dilaksanakan oleh pembuat kebijakan dan pendamping masyarakat (Widjanarko, 2015).

Penelitian yang dilakukan Pusat Penelitian dan Pengembangan (Puslitbang) Universitas Muria Kudus bekerjasama dengan Pemerintah Kabupaten Kudus di bulan September - Desember 2004 tentang peran perempuan dalam pengelolaan lingkungan hidup di Kabupaten Kudus menemukan beberapa temuan yang menarik mengenai peran perempuan dalam mengelola lingkungan hidup. Salah satu aspek menunjukkan kepedulian ke semua responden yang berjumlah 450 orang dalam berpartisipasi melestarikan lingkungan hidup di sekitarnya, yang telah direalisasikan dalam perilakunya, terbanyak ada 331 orang $(19,95 \%)$ dari 450 responden memberikan jawaban telah membuang sampah di tempatnya, kemudian 302 orang $(18,20 \%)$ dari 450 responden telah melakukan penghematan penggunaan listrik di rumah, 299 orang (18,02 \%) dari 450 responden melakukan penanaman tanaman dan menyiraminya, selanjutnya upaya-upaya penghematan pemakaian air dilakukan oleh 288 orang (17,36 \%) dari 
450 responden, sedangkan 138 orang $(8,32 \%)$ dari 450 responden menggunakan tanaman obat sebagai obat alternatif dalam keluarga dan 2 orang $(0,12 \%)$ mengaku pernah mengikuti kerja bakti (Widjanarko dkk, 2004).

Penelitian yang dilakukan Demartoto berjudul "Pemberdayaan Perempuan Dalam Pariwisata Berbasis Komunitas (Studi Kasus Tiga Desa Wisata Di Jawa Tengah)". Dari penelitian tersebut mengkaji peluang dan hambatan perempuan dalam memanfaatkan kegiatan pariwisata berbasis komunitas di Desa Kliwonan, Desa Barjo dan Desa Samiran. Peluang perempuan dalam memanfaatkan potensi wisata tersebut berupa penyediaan usaha wisata guna meningkatkan kapasitas diri dan mengembangkan relasi dengan wisatawan. Hambatan internal yang dihadapi perempuan yaitu masih terbatasnya skill dan modal usaha. Hambatan eksternal berupa kondisi masyarakat yang masih bias gender, kurang intensifnya koordinasi dan kerjasama antar sektor yang terkait. Perempuan di tiga desa penelitian lebih banyak menduduki posisi sebagai pekerja. Pemberdayaan perempuan di Desa Kliwonan dapat meningkatkan keahilan dan ketrampilan perempuan sehingga peran yang dijalankan lebih sebagai inisiator, investor, pengelola dan pengawas. Perempuan di Desa Kliwonan memiliki tingkat ekonomi yang lebih baik sehingga tingkat ketergantungan terhadap laki-laki menjadi lebih rendah dibandingkan dengan Desa Barjo dan Samiran.

Jika selama ini, orang berpikir bahwa upaya pelestarian alam adalah tugas para pecinta alam, peneliti, pendidik, masyarakat adat, organisasi non pemerintah dan pemerintah semata, kini sudah waktunya untuk merubah pikiran seperti itu. Siapapun berperan dalam upaya pelestarian alam dan lingkungan, termasuk perempuan. Apa peran perempuan dalam pelestarian lingkungan di Kepulauan Karimunjawa? 
Penelitian ini bertujuan untuk menganalisis peran perempuan dalam melestarikan lingkungan di Kepulauan Karimunjawa dengan penelitian kualitatif dengan pemilihan informan berdasarkan tiga kriteria yaitu berjenis kelamin perempuan, mempunyai kemampuan komunikasi secara verbal dan memiliki peran dalam hubungan sosial di masyarakat. Pengumpulan data dilakukan dengan wawancara dan pengamatan. Untuk melakukan analisis data, penelitian ini menggunakan analisis data berupa koding. Poerwandari (1998) berpendapat bahwa koding bertujuan untuk dapat mengorganisasikan mengsistematiskan data secara lengkap dan mendetail sehingga dapat memunculkan gambaran tentang topik yang dipelajari.

\section{B. Pembahasan}

\section{Perempuan dan Lingkungan}

Di akhir abad 20, timbul berbagai gerakan kesadaran masyarakat yang menaruh perhatian terhadap keadaan lingkungan.Hal ini berkaitan dengan kesadaran untuk menjaga planettempattinggal manusia menjadibersih, sehat dan hijau. Berbagai organisasi lingkungan bermunculan serta barang-barang recyled menjadi kecenderungan gaya hidup orang-orang kota dan bahkan dalam berliburan ada kegiatan yang kemudian dikenal dengan sebutan ekoturisme. Proses mengenal lingkungan terus digulirkan, anak-anak sejak usia dini diberi pendidikan lingkungan hidup, diajari menyayangi binatang dan lingkungannya dan memberi perhatian pada binatang langka.

Sejak kecenderungan peduli lingkungan ini merebak bukan saja di kalangan organisasi non pemerintah atau lembaga swadaya masyarakat saja tetapi juga di pemerintahan, tetapi banyak pihak yang tidak menyadari bahwa isu lingkungan sangat berkaitan erat dengan isu perempuan. 
Ekofeminisme di Indonesia muncul sebagai reaksi atas terpinggirnya perempuan dalam proses pembangunan dan semakin rusaknya alam karena dampak pembangunan yang tidak berpihak pada alam. Di tengah kondisi masih dominannya logika dualistik, termasuk dalam pemikiran feminisme, maka ekofeminisme bisa menjadi salah satu alternatif yang mencerahkan. Ekofeminisme yang pertama kali diperkenalkan feminis Perancis, Francoise d'Eaubonne, pada tahun 1974 lewat buku Le Feminisme ou La Mort.

Ekofeminisme memiliki nilai lebih karena tidak hanya memfokuskan diri pada subordinasi perempuan, tetapi juga subordinasi alam-lingkungan (ekosistem) di bawah kepentingan manusia. Dengan demikian, ekofeminisme sekaligus mengkritisi pilar-pilar modernisme yang lain, yakni "antroposentrisme" (faham yang menempatkan posisi dan kepentingan manusia lebih di atas kepentingan makhluk lain) dan "androsentrisme" (faham yang menempatkan posisi dan kepentingan laki-laki lebih tinggi dibandingkan dengan posisi dan kepentingan kaum perempuan).

Ekofeminisme pun kemudian menemukan titik tolak bersama (common denominator) yang tepat menggambarkan betapa energi feminitas sangat berpotensi menjaga kelestarian lingkungan hidup, kelestarian planet bumi sebagai planet tempat kita (lelaki maupun perempuan) hidup.Ekofeminisme dengan sangat baik juga mampu menerangkan betapa hipermaskulinisme ternyata juga berperan pula terhadap kerusakan ekosistem (Widjanarko, 2012).

Berdasarkan doktrin hukum HAM internasional, menurut Karel Vasakdalam Saleh (2005), hak atas lingkungan hidup merupakan salah satu hak yang termasuk dalam kategori generasi ketiga di mana yang mendapatkan perlindungan tidak hanya hak yang bersifat individu tetapi juga hak- hak kolektif. Paul Sieghart mengidentifikasi 6 golongan hak- hak kolektif, 
yaitu : (i) hak atas penentuan nasib sendiri; (ii) hak atas perdamaian dan keamanan internasional; (iii) hak untuk menggunakan kekayaa $\mathrm{n}$ dan sumber daya alam; (iv) hak atas pembangunan; (v) hak kaum minoritas, dan (vi) hak atas lingkungan hidup.

Oleh Kasim (2004) dikatakan perkembangan terkini berdasarkan Konvensi HAM Wina 1993, tidak terdapat lagi perbedaan kategorisasi HAM berdasarkan perkembangan generasi, kepentingan yang dilindungi, maupun dikotomi antara hak- hak sipil dan politik dengan hakhak ekonomi, sosial, dan budaya karena HAM pada prinsipnya saling terkait (interdependence) dan tidak dapat dipisahkan (indivisible).

Sistem budaya patriarkhi menyebabkan persoalan yang dihadapi perempuan secara struktural, yang menunjukkan hubungan laki - laki dan perempuan tidak setara. Adanya kebijakan yang tidak berpihak pada perempuan dan semakin lemahnya peran negara melindungi warganya akibat tekanan globalisasi.

Jurnal Perempuan No. 48 Tahun 2006, Pengetahuan Perempuan, hal.129menyatakan Temu Nasional Aktivis Perempuan Indonesia tanggal 31 Agustus 2006 menghasilkan 12 Agenda khusus gerakan perempuan untuk tahun 2006-2011. Salah satu agenda yang terkait dengan pengelolaan lingkungan hidup adalah agenda tentang perempuan dan Sumber Daya Alam (SDA) yang meliputi :

1. Mengintegrasikan isu SDA dalam gerakan sosial lain

2. Mengkampanyekan hak asasi perempuan dalam pengelolaan SDA

3. Pengelolaan SDA berbasis komunitas yang responsive gender (misalnya petani, nelayandan lain-lain)

4. Menuntut tanggung jawab negara dan korporasi 
yang merusak lingkungan hidup dan melanggar hak asasi perempuan dan adat.

5. Menolak pembayaran utang luar negeri yang bersumber dari eksploitas i SDA.

6. Advokasi kebijakan dan kasus pengelolaan SDA.

Undang- Undang No. 32 Tahun 2009 tentang Perlindungan dan Pengelolaan Lingkungan Hidup (UUPPLH) telah memberikan perubahan yaitu bersifat demokratis, memberikan kewenangan luas kepada pemerintah daerah dan lebih mengutamakan keterlibatan masyarakat dalam memberikan kontrol terjadinya kerusakan lingkungan hidup.

Peran perempuan secara implisit dijelaskan dalam pasal 70 tentang peran masyarakat. Peran perempuan dalam perlindungan lingkungan hidup menurut UndangUndang Perlindungan dan Pengelolaan Lingkungan Hidup dapat berupa pengawasan sosial dan peran perempuan dalam pembuatan kebijakan Lingkungan Hidup melalui lembaga legislatif. Kuota perempuan 30 persen dalamDPR/DPRD memberikan peluang keikutsertaan perempuan dalam Rencana Penyusunan Pengelolaan Lingkungan Hidup (RPPLH) dan Kajian Lingkungan Hidup Strategis (Darmastuti dkk, 2012).

\section{Pengetahuan dan Peran Perempuan dalam Pelestarian Taman Nasional Karimunjawa}

\section{a. Mulai dari Diri Sendiri}

Taman Nasional Karimunjawa adalah salah satu kawasan pelestarian alam di Kabupaten Jepara, Propinsi Jawa Tengah yang memiliki ekosistem asli.Taman nasional ini dikelola dengan sistem zonasi yang dapat dimanfaatkan untuk tujuan penelitian, ilmu pengetahuan, pendidikan, menunjang budidaya, pariwisata dan rekreasi. 
Balai Taman Nasional Karimunjawa (BTNKJ) merupakan penanggungjawab pengelolaan ekosistem kawasan Taman Nasional Karimunjawa dalam rangka konservasi sumberdaya alam hayati dan ekosistemnya berdasarkan perundang-undangan yang berlaku.

Keberadaan Balai Taman Nasional sudah diketahui ibu-ibu dibawah ini., Ibu guru A yang menjadi salah satu informan dalam penelitian ini mengatakan:

"Tahu sih, karena pernah dapat undangan dari BTN (Balai Taman Nasional), ajakan menanam bakau bersama murid-murid, bulan Januari atau Februari gitu. Biasanya dapat undangan dari dinas perikanan, sama murid-murid bersih-bersih pantai. Kalau di sekolah sendiri tiap dua minggu sekali, di hari Jumat kita bersih-bersih. Untuk bakti sosial kita lakukan 2 kali dalam satu tahun, seperti pas hari-hari pramuka ada perkemahan"

Hal yang sama juga dikatakan oleh pemilik rumah inap bernama $\mathrm{Y}$, sebagai berikut:

"Iya, tahu.Pengelolaannya harus dari pemerintah juga dan dari pemerintah diawali dari masyarakat.Kepekaan masyarakat pada lingkungannya. Jadi menjaga taman nasional ini dari, terutama sampah"

Begitu pula dengan ibu yang dikenal sebagai Ketua Bank Sampah,

“Nggeh” (“sudah”).“Niku kok kadose saking BTN kok tahun pinten nggeh mas, kulo supe. Niko awal-awale saking BTN"("Informasi itu dari BTN, tahunnya saya lupa"

Sejak disadari betapa pentingnya melibatkan perempuan untuk mengelola lingkungan karena sifat yang dimiliki perempuan yakni ketelatenan, ketekunan, 
dan memiliki kegiatan yang terkait langsung dengan lingkungannya maka muncul gagasan untuk melibatkan perempuan dalam pengelolaan lingkungan. Pengelolaan lingkungan mulai dari lingkup mikro sampai lingkup makro.

Salah satu faktor terpenting dalam menjaga kelestarian lingkungan adalah adanya peran perempuan, jadi perempuan tidak hanya menjadi pelengkap dalam simbol dan mitos yang acap kali terjadi dalam lingkungan hidup, tetapi peran perempuan juga merupakan salah satu fungsionalitas dalam menjaga keseimbangan dalam turut melestarikan lingkungan.

Salah satunya peran yang diungkap oleh Ibu H dalam turut mengelola sampah sebagai berikut:

"Sekarang ibu-ibu sini ya ikut membersihkan lingkungan, apalagi sekarang banyak wisata, bisa berjualan kan harus ikut menjaga lingkungan".

Diceritakan lagi, bagaimana dalam melestarikan lingkungan juga terkait dengan upaya melakukan pendidikan lingkungan yang dimulai sejak kecil dan tidak mengenal usia, sebagai berikut ini:

"Iya, saya kalau pergi ke posyandu, membiasakan anak saya membawa kardus minuman untuk tempat sampah. Cucu saya mengikuti peduli lingkungan, kalau makan yang ada bungkusnya, kalau sudah selesai segera membuang di tempat sampah.Awalnya ikut ke posyandu, ibunya bilang bungkusnya dibuang di tempat sampah, jadi kebiasaan, di rumah juga begitu, kalau habis makan yang ada bungkusnya dibuang tempat sampah, saya memang ceriwis untuk mengajarkan kalau dibiarkan tidak tahu gimana nantinya".

"Orang yang datang di posyandu bukan anak kecil saja, ada orang tua, lansia,saya berfikir yang lansia membawa 
sampah pulang, saya yang masih muda, mengantar anak kok kalah"

Langkah lain dilakukan oleh Ibu guru A, selain mengajak murid-murid menjaga lingkungan di sekitar sekolah, yang dilakukan sebagai berikut:

“Saya juga aktif di organisasi PKK, PKK desa kemarin itu ada agenda menanam cabai, mungkin itu bisa menambah penghijauan, terkadang PKK mengadakan tanam bakau bekerja dengan BTN".

Selain itu, seperti yang dituturkan kepada peneliti:

"Saya nggak menanam pohon banyak-banyak, saya hanya menanam seperti jeruk dan tanaman yang sehari-hari kita butuhkan, misalnya cabai. Saya suka berkebun, di dukung sama tanah yang ada di sekitar rumah, jadi lumayan-lah, kalau cabai harganya naik, saya nggak kesusahan"

Upaya melestarikan lingkungan dalam bentuk yang berbeda juga dilakukan ibu Y pemilik rumah penginapan:

“Untuk penggunaan air di penginapan, kita punya sumur bor. Untuk penghematan airnya kita punya penyerapan sendiri kayak biopori. Memang sanitasinya kita.. kebetulanowner dari kami juga bergerak di lingkungan hidup, teknik lingkungan jadi benar-benar diperhatikan untuk masalah sanitasinya. Jadi gimana caranya meskipun di pinggir laut gini kita tetap dapat air bersih"

Sedangkan untuk keberadaan sampahnya, hal yang menarik telah dilakukan oleh Ibu Y, sebagai berikut:

"Untuk pembuangan sampahnya, kita gunakan sanpahnya, kita bikin pupuk kompos,, kita juga kadang suka menanam. Menanam sendiri, terus kayak bikin tanaman sawi. Jadi kita bikin pupuk di belakang" 
Untuk sampah non-organik dan upaya melestarikan lingkungan yang lain, diceritakan lebih lanjut :

“Biasanya dibuangnya ke TPA, suami saya biasanya yang mengelola. Kadang ada sampah-sampah dari laut, sampah kiriman. Apalagi kalau musim "baratan" kita juga yang bersihin disini.Karena kan kita juga yang jaga. Kayaknya sekarang lagi gencar-gencarnya yayasan untuk mengelola sampah. Inikan lagi ada program menjaga laut. Kalau bukan kita yang menjaga, siapa lagi. Ini juga kadang untuk kayak menjaga terumbu karang, kita lebih sosialisasi sih ke tamu kayak ini kita bikin (menunjukkan banner tentang pelestarian terumbu karang dan panduan sebelum snorkeling.) cegah gitu loh biar taman nasional itu dijaga. Kita lebih mencegah aja sih"

\begin{abstract}
"Itu ada cabai, serai, bumbu-bumbu dapur, kemangi sama sawi, Ini ada sampah-sampah dari botol plastik dicoba bikin sesuatu, nantikan di hias atau gimana jadi bisa jadi hiasan. Ini masih rencana sih baru ngumpulin botolbotolnya di belakang"
\end{abstract}

\title{
b. Berbagi Kepedulian Terhadap Lingkungan
}

Ibu ketua bank sampah mengatakan bahwa perlunya mengajak-ngajak tetangga untuk ikut peduli lingkungan melalui dengan memberi contoh secara langsung mulai memberikan tas plastik besar ke orang-orang untuk tempat mengumpulkan botol, hingga penimbangan. Beliau yang langsung mengambil, mengkoordinir di rumah bagi tetangga dekat dan membawa songkroyang berisikan tiga palstik besar ke kelompok, satu untuk botol air minuman kemasan, satunya untuk air minum kemasan yang berasa saat penimbangan.

Hal yang serupa juga dilakukan ibu A, ini penuturannya: 
“Di sini itu harus green go green, apalagi di pelajaran saya, perhotelan kan di bidang jasa, kalo perhotelan tidak bersih kan tidak bagus dilihat sama tamu jadi kita harus mengaktifkan murid-murid untuk bersih-bersih lingkungan terutama dari kelas mereka sendiri. Dari guru mencontohkan kita membuang sampah pada tempatnya, baru menyuruh muridnya" dan "Biasanya saat ada tamu, murid-murid mendukung kebersihan, sampah diambilin, ada yang ikut komunitas bersih pantai"

Hal yang kurang lebih sama, dilakukan oleh ibu pemilik penginapan.Ini ceritanya:

“Kalau yang ada di sini. Misal kayak pagar itu kita buat dari botol bir. Jadi dari pada botolnya nggak kepakai jadi kita buat pagar jadi hiasan.Banyak sih, kayak pohonpohon itu (menunjuk ke salah satu sudut penginapan) sebenarnya kayak itu sampah dari laut, kayu-kayu dari laut".

“Oh iyaa..Kemaren sih kayak apa sih itu yaa kayu-kayu yang kita temuin kadang kami manfaatin jadi hiasan. Gitu aja sih.biar lebih bermanfaat dan estetikanya kata orang nyeleneh, tapi kalau buat kita, apanih?? Biasa dibuat apa nih?? gitu"

Upaya pelestarian lingkungan hidup, dilatarbelakangi oleh harapan-harapan seperti sampah yang dapat diatasi lebih baik dari tahun ke tahun dengan adanya paguyuban (wawancara ibu A). Pengelolaan sampah yang ada di Karimunjawa mengalami peningkatan kualitas dari yang dulunya dibakar atau dibuang di laut juga peningkatan ekonomi warga karena dulunya bahkan pengelolaan sampah dipungut iuran yaitu dua puluh ribu pada tukang sampah. Hanya saja untuk membangun kesadaran warga Karimunjawa harus secara perlahan. 
“Untuk itu, orangnya harus sabar, kalau saya bilang orang Karimun susah dikasih tahu.Kalau di dermaga sudah dikasih tong sampah, orang Karimun sendiri bersama orang yang mincing ikan membuang sampah seenaknya sendiri, minta di atur seperti dulu, jaman dulu tidak ada wisata, terserah saja. Sekarang ada wisata harusnya lingkungannya bersih".

Sedangkan ibu Y menyoroti masalah lingkungan yang berkaitan sampah dengan kelestarian laut. Berikut penuturannya pada peneliti:

“Lautnya, di lingkungan lautnya sendiri. Biasanyakan kita kalo perjalanan ke laut kan bawa makanan, kebayakan sampahnya dibuang di laut. Jadi kalau tour laut, bawa sampah sendiri atau sampahnya dibawa pulang"

Lain lagi yang diungkapkan harapan ibu pemilik penginapan sebagai berikut di bawah ini:

“Harapannya sih yang pasti pengen lebih baik lagilah, maksudnya lebih bisa untuk kami bisa lebih maju lagi.Kalau untuk Karimun sendiri lebih diperhatikan pemerintah".

Perempuan memiliki arti penting dalam menjaga kelangsungan pembangunan secara berkelanjutan. Dilihat dari jumlahnya perempuan sebagai sumberdaya manusia merupakan modal potensial sebagai dasar pelaksanaan pembangunan. Perempuan selayaknya ditempatkan sebagai subyek tidak hanya menjadi obyek pembangunan seperti yang selama ini berlaku.

Disadari bahwa pelaksanaan pembangunan yang dicanangkan selama ini justru kurang berpihak pada perempuan bahkan cenderung meminggirkan perempuan mulai perencanaan dan pelaksanaan pembangunan di tingkat mikro hingga makro. Marjinalisasi perempuan 
secara sadar maupun tak sadar diterima saja oleh perempuan sebagai kodrat perempuan.

Perempuan tersisihkan dari kesempatan memperoleh peningkatan pengetahuan, keterampilan, pendidikan, modal, serta pelayanan kesehatan. Rendahnya kualitas sumberdaya perempuan karena kesempatan yang tak dimiliki perempuan untuk meningkatkan kualitas, menjadi cara untuk pembenaran betapa ketidakberdayaan perempuan. Alasan mengenai ketidakberdayaan perempuan telah menempatkan perempuan kurang dilibatkan dalam berbagai kegiatan di masyarakat. Perempuan dianggap kurang mampu diberi tanggung jawab di masyarakat.

Meningkatkan peran serta perempuan merupakan langkah yang perlu mendapat perhatian agar perempuan mampu untuk berperan sebagaimana lawan jenisnya dalam setiap kegiatan di masyarakat. Perempuan selama ini banyak dilibatkan pada kegiatan domestik mulai dari penyediaan air bersih, pengelolaan tugas-tugas rumah tangga seperti memasak, mencuci, berbelanja kebutuhan rumah tangga. Tugas-tugas yang kurang memiliki makna ekonomi sehingga perempuan menjadi kelompok yang terikat dalam ketergantungan dengan laki-laki. Lakilaki yang banyak bergerak pada kegiatan produktif dan mempunyai nilai ekonomi (Widjanarko, 2004).

\section{Menimbang Peran Perempuan dalam Aksi Lingkungan}

Dalam kehidupan sosial nyata, membawakan peran berarti menduduki suatu posisi sosial dalam masyarakat. Dalam hal ini seorang individu juga harus patuh pada skenario, yang berupa norma sosial, tuntutan sosial dan kaidah-kaidah (Suhardono, 1994). 
Artinya, keberadaan pengelola bank sampah, guru serta pemilik rumah penginapan memainkan perannya masing-masing dalam aturan sosial yang sudah disepakati oleh masyarakat. Melalui cara masing-masing berperan sebagai pelaku yang peduli dengan lingkungan serta memiliki perilaku nyata dalam menjaga kelestarian lingkungan di Kepulauan Karimunjawa.Peran ini menjadi begitu penting karena berhubungan dengan kontribusi mereka dalam menjaga pelestarian lingkungan di Kepulauan Karimunjawa.

Ditambahkan Biddle \& Thomas (1966) yang menyatakan bahwa peran adalah serangkaian rumusan yang membatasi perilaku-perilaku yang diharapkan dari pemegang kedudukan tertentu sehingga orang yang terlibat dalam interaksi sosial dapat membagi dirinya dalam dua bagian. Pertama, sebagai pelaku yaitu orang yang sedang berperilaku menuruti suatu peran tertentu, misalnya sebagai pengelola bank sampah, maka seseorang akan berperan sebagai seorang yang peduli lingkungan terkait dengan cara membuang sampah dan memberikan contoh pada orang lain untuk membuang sampah ditempatnya. Kedua, sebagai sasaran atau orang lain yaitu orang yang mempunyai hubungan dengan pelaku dan perilakunya, misalnya sebagai anggota bank sampah maka ia akan menuruti keputusan pimpinan bank sampah yang peduli lingkungan untuk tidak membuang sampah sembarangan.

Hal ini sesuai dengan pendapat Suprapto (1990) menerangkan bahwa perempuan dapat berpartisipasi sebagai agen "bersih-lingkungan" dengan memberikan pendidikan dan wawasan kepada keluarga, khususnya anak-anak mengenai lingkungan. Pendidikan itu bisa dapat berupa pelajaran kepada mereka untuk tidak membuang sampah sembarangan.

Selainitu, menurutDana (2009) perempuanjuga dapat 
dilibatkan secara aktif dalam pengelolaan sampah rumah tangga dengan cara memisahkan sampah rumah tangga bedasarkan jenisnya. Perempuan juga dapat berpartisipasi untuk mengurangi pencemaran lingkungan dengan berperan dalam menentukan produk rumah tangga yang ramah lingkungan.

Dana (2009) juga berpendapat bahwa perempuan dapat menjadi pendidik lingkungan. Perempuan atau ibu merupakan media edukasi pertama bagi anak-anak. Melalui ibu, pendidikan dan penyadaran mengenai kepedulian terhadap lingkungan dapat ditanamkan pada anak-anak sejak dini. Dari penerapan pola pengelolaan sampah dan pemilihan produk yang ramah lingkungan yang dilakukan dalam sebuah keluarga, anak akan ikut terbiasa dalam menjaga lingkungan. Jika nantinya kebiasaan dan kesadaran lingkungan mengakar dalam diri anak-anak, maka pada masa depan akan tercipta generasi yang peduli lingkungan.

Berbeda dengan penelitian yang dilakukan oleh Tran dan Walter (2014) dalam jurnal Annals of Tourism Research berjudul "Ecotourism, Gender and Development in Northern Vietnam". Penelitian tersebut mengkaji bagaimana dimensi gender terintegrasi dalam perencanaan dan implementasi dari ekowisata berbasis masyarakat di Giao Xuan, Vitenam. Penelitian menunjukan bahwa integrasi antara dimensi gender dengan kegiatan ekowisata memberikan dampak positif bagi perempuan lokal. Perempuan di Giao Xuan tidak hanya mendapatkan penghasilan tetapi juga kepercayaan diri dan diperhitungkannya suara mereka dalam berbagai aktivitas. Meskipun demikian, perempuan di Giao Xuan tetap tidak mampu mengurangi penggunaan alkohol dan kekerasan yang dilakukan oleh laki-laki. 
Diperjelas oleh Penelitian Suardana (2010) dalam Jurnal Piramida Vol.6 No.2 Universitas Udayana berjudul "Pemberdayaan Perempuan di Kawasan Kuta sebagai Upaya Peningkatan Kualitas Pariwisata Bali" mengkaji keterlibatan perempuan di sektor pariwisata Pantai Kuta. Suardana menemukan bahwa keterlibatan perempuan terbagi menjadi dua strata yaitu strata atas dan menengah ke bawah. Keterlibatan perempuan strata atas yaitu sebagai pemilik dan pekerja hotel di tingkatan majerial. Perempuan pada strata bawah terlibat sebagai pekerja dalam proses produksi souvenir, penjual souvenir dan pada sektor informal. Perempuan berpendapat bahwa keterlibatannya memberikan manfaat sosial yaitu lebih baik dalam mengutarakan pendapat, manfaat budaya yaitu dapat melestarikan kebudayaan dan manfaat ekonomi yaitu memiliki penghasilan sendiri.

\section{Simpulan}

Peran perempuan dalam memelihara lingkungan di Kepulauan Karimunjawa, dilakukan dengan mengelola sampah, yang dilakukan dengan membentuk bank sampah dan mengajak keluarga serta orang lain untuk mengelola sampah. Sedangkan informan yang memiliki rumah penginapan juga menggunakan air secara bijak dan memilah sampah dalam bentuk sampah organik dan nonorganik.Untuk informan yang berprofesi guru selain menanam tanaman yang bisa diperlukan sehari-hari juga mengajak muridnya dalam menjaga lingkungan di sekitar sekolah dan upaya melakukan bersih-bersih pantai. 


\section{DAFTAR PUSTAKA}

Badan Pusat Statistik, 2013. Kecamatan Karimunjawa dalam Angka.Kabupaten Jepara

Biddle, B.J., \& Thomas, E.J. (Editor). 1966, Role Theory: Conceps and Research. New York: Wiley.

Dana D.W.. 2009.Perempuan dan Lingkungan: e-Wanita Ed. 24, Vol. 2009. (internet). (diunduh 6 Juli 2018). Diunduh dari: http:/ / wanita.sabda.org/ perempuan_ dan_lingkungan

Darmastuti, A. Budiono, P; Maryanah, T dan Handayani, W.H. 2012.. "Peningkatan Kesadaran Perempuan Terhadap Pengelolaan Lingkungan Wilayah Pesisir di Kelurahan Bumi Waras".Dalam .Seminar Hasil-Hasil Penelitian dan Pengabdian Kepada Masyarakat. Bandar Lampung: Dies Natalis FISIP Universitas Lampung

Demartoto. 2012.Pemberdayaan Perempuan dalam Pariwisata Berbasis Komunitas (Studi Kasus Tiga Desa Wisata di Jawa Tengah). Disertasi. Program Doktor Sosiologi. Fakultas Ilmu Sosial dan Ilmu Politik Universitas Gadjah Mada.

Jurnal Perempuan No. 48 Tahun 2006. Berita, Pengetahuan Perempuan. Jakarta: Gramedia.

Kasim, I., 2004."Hak atas Lingkungan Hidup dan Tanggung Gugat Korporasi Internasional", dalam SUAR Volume 5 No. 10 \& 11

Poerwandari, E. K., 1998. Pendekatan Kualitatif dalam Penelitian Psikologi.Jakarta : LPSP3 Fakultas Psikologi Universitas Indonesia 
Musssadun dan Laksono .2014.“Dampak Aktivitas Ekowisata di Pulau Karimunjawa berdasarkan Persepsi Masyarakat", dalamn JurnalTeknik PWKVolume 3 Nomor 2 Tahun 2014. Online : http:/ / ejournal-s1.undip.ac.id/index.php/pw

Saleh, R,M. 2005. Ecoside : Politik Kejahatan lingkungan dan Pelanggaran Hak Asasi Manusia. Jakarta: Walhi

Suardana, I.W.2010. Pemberdayaan Perempuan di Kawasan Kuta Sebagai Upaya Peningkatan Kualitas Pariwisata Bali. ojs.unud.ac.id/index.php/piramida/ article/download/3002/2160. Diunduh 4 Januari 2017

Suhardono, E. 1994.Teori Peran: Konsep, Derivasi dan Implikasinya. Jakarta: PT Gramedia Pustaka Utama.

Suprapto I.A. 1990. Pendidikan Sosial dan Peranan Wanita dalam Pengelolaan Lingkungan. Dalam: Noerhadi TH, Hubeis AVS, editor. Dinamika Wanita Indonesia. Seri 01: Multidimensional. Jakarta: Pusat Pengembangan Sumberdaya Wanita.

Tran, L dan Walter, P . (2014). “Ecotourism, Gender and Development in Northern Vietnam", dalam. Journal Annals of Tourism Research 44 (2014) 116-130

Undang-Undang No. 32 Tahun 2009 tentang Perlindungan dan Pengelolaan Lingkungan Hidup

Widjanarko, M., Indaryani, M., Indriani. F. 2004. Peran Perempuan dalam Pengelolaan Lingkungan Hidup di Kabupaten Kudus. (Laporan Penelitian). Kudus: Puslitbang UMK-Pusat Kajian Gender dan Pemerintah Kabupaten Kudus (dipublikasikan di Warta APTISI Wilayah VI Jawa Tengah, Edisi Januari 2006, ISSN: 0261-5341). 
Widjanarko, M. 2012. Psikologi Lingkungan: Teori dan Praktek. Kudus: Badan Penerbit Universitas Muria Kudus.

Widjanarko, M. 2015. Perempuan Merawat Komunitas Ketika Bencana: Kajian Ekologi di Desa Rahtawu Kudus, Pegunungan Muria. Jurnal Perempuan Vol. 20, No 3, Agustus 2015. ISSN: 1410-153X 